\title{
The Positioning and Development of Yunnan Folk Music Song and Dance Performances
}

\author{
Qinghua $\mathrm{Lu}^{1}$ \\ ${ }^{1}$ School of music and dance, Qujing Normal University, Yunnan, 655011 \\ a Luqinghua66@126.com
}

Keywords: Yunnan folk, Song and dance music, development.

\begin{abstract}
The ethnic minorities in yunnan is numerous, the ethnic cultural resources rich, rich and colorful folk song and dance music unique personality. Through combing analysis of all previous national ethnic theatrical festival and yunnan folk song and dance performance profile. The significance of performance, and put forward the yunnan folk song and dance performance in the direction of innovation and development.
\end{abstract}

\section{Introduction}

After the founding of new China, the national implementation of national policy and cultural policy, the minority folk art culture of the rescue, support, development. In 1950s the central government and local governments at all levels of organizations of different sizes of the variety show, has become an important measure of developing national culture, then, in the maintenance of national discourse, the country greatly small folk art festival blossom everywhere, this will emerge in an endless stream, become a literary system is enduring a. [1]: in 1953 the first national folk music and Dance Festival "," 1957 the second national folk dance festival ", 1964" national minority art observation performance ", the scale and impact of this time, the historical status of the most special, actors from the remote mountainous areas of poor minority folk artists. The delegation of Yunnan province [2] ginseng, play actor Yi, Bai, Hani, WA, Lahu, Naxi, Jingpo, Brown, Nu, Derung, Achang, Pumi, show the Naxi dance (Performer: ah hot and Naxi Fengxiang Zhao Xingwen); Yi Dance: the joy of Yi (Yi performer Li Zhengxing); Dabenqu (Bai Bai folk folk artists in Xian, Qing Shun), Lahu family Lusheng Music Solo (performer Lahu family about the harvest) and other programs. [3]

After the reform and opening up, the first national ethnic arts festival held in September 20, 1980 to October 20th in Beijing, this is the "Cultural Revolution" after the first large-scale national arts festival, caused a sensation in all aspects of the society. In 2001 sixteen the party held on the eve of the second national minority festival held in Beijing, the first national literary works, its prosperity, with a galaxy of talents gratifying situation, the provisions of the central 5 years after hosting a national minority festival; on September 5, 2006 to 25 of the third ethnic arts festival held in Beijing. The theme of "carrying forward the fine traditional culture of ethnic minorities, to promote the common prosperity of all ethnic groups". This will cover luxury scenery before any one nation. Large dance [4] from Yunnan "" dance "clouds (90 minutes show) gave the audience left a deep and shocking impression. In Yunnan ethnic song and dance and music show alternate Yunnan colorful folk art treasures, the folk artists of the original works, there is from the folk art after refining a. The "seaweed", "pendulum" cavity, "Peacock Dance" has entered the State Department announced the first batch of national intangible cultural heritage; from June 7, 2012 to July 7th held the fourth national ethnic arts festival in Beijing, the delegation of Yunnan Province, the original ecological folk music collection "Yunling" day Lai won a number of awards (gold medal play best director award, the award program, actor award) achieved good results. After 1950s, the state attaches great importance to the traditional folk art to formulate corresponding policies, governments at all levels to actively take measures to rescue the scattered folk art treasures, arousing people protection consciousness. Such as the rural organization in 1956 Qujing area artists South Road, Luo County deep equality folk songs, folk songs, dance, lantern collection of tunes, traditional repertoire of folk 
cultures such as national art, which lasted February. [5] Festival is from the central and local governments to take measures to protect important folk art.

\section{Overview of Yunnan folk music song and dance performances}

Yunnan is our country most minority provinces, according to the 1990 fourth national census data distribution of 56 ethnic groups in Yunnan have 52, of which the population of more than 5000 people in a 26 nation, in addition to the Han nationality, there are 25 ethnic minorities, there are 15 unique people: Hani, Yunnan Bai, Derung etc.. The national distribution is large mixed characteristics of small settlements. Yunnan in the thousands of years of cultural heritage, rich folk cultural resources, rich cultural heritage, unique folk customs and colorful folk festival culture, colorful costumes culture, folk singing and dancing of rich and colorful, unique personality. After repeated investigation, the collection of folk dance, 1255 dance routines 7818, 6950, 547, 471 percussion folk dance legend first, 1352 folk songs etc.. [6]

In 1996, the CPC Yunnan Provincial Committee, first proposed the goal of building a "cultural province" characteristic, Yunnan Provincial Department of culture, research on Ethnic Affairs Commission of Yunnan province decided to move the province's important national folk dance music festival held every two years. We must focus on the "national art exhibition exhibition style, carry forward the fine traditional culture" as the theme, adhere to the "orientation and the" double hundred "policy, conscientiously implement the" People's Republic of China intangible cultural heritage intangible cultural heritage protection law "should pay attention to the authenticity and integrity and inheritance requirements", participating programs are based on national, provincial and prefecture (city) level intangible cultural heritage of music and dance class list of projects, pay attention to actively develop local traditional folk culture resources, through the organization of field research, at the recommendation of appropriate arrangement and director, to protect and carry forward the excellent national traditional culture based on innovation and development for the purpose, in November 6, 1997, the province's first the national folk dance music performances (then known as "the national folk art exhibition") opened in Kunming Show, which lasted 4 days, with a strong lineup, showing the 66 program team of 17 prefectures and cities in our province, which were selected in the 29 "mass culture emerged cloud Award", "a", "bell game plus Diane", "Oh" De De age A-Mei form, unique the audience was impressed by the outstanding works, to be held on November 2015 in Mengzi ninth Yunnan ethnic folk dance music performances were accumulated nearly 500 outstanding works, such as "Mei Ge" karma "," Alas miles Dai dance "," red deer dance Lusheng foot hall "and so on. The team has continued to grow and develop, and there are more than one thousand folk artists and folk artists. Scientific performance group setting: such as: the first group is the original form of the program; the second group is the appropriate processing and editing the derived form in music rhythm, dance skills, plot and clothing collocation etc.; the third group is the refined creation of multiple components, but still retains the ethnic culture and art, the gene has the the culture of the program. More than ten years, always adhere to in every national song and dance music show director meeting, before the start of a line of literary and art workers, mainly engaged in national folk culture protection experts assembled together, sum up the experiences of the previous and determine the new standard, every have expert jury for argument and develop standards and business, always adhere to the principle of fair justice, commendation and reward for the to show excellent programs, makes the singing and dancing performance always stay in the right direction, and constantly improve, constantly seeking exploration summing up experience and reform. Such as change the place of performance: starting from the sixth, each year, singing and dancing performance are chosen to host on the ground state, was held in September 2009 in yuxi respectively in November 2011 the 6th, held in the region of the 7th, 2013 in lincang on December 8th, in November 2015, the 9th in mengzi. Add performances: starting from the 7th not only indoor concentration on stage performance, also set up a good show to the countryside tour activities, and further implement the national folk song and dance art "from the masses, to the masses" strategy; Award setting: in addition to gold and silver and bronze medal, also joined the prize. Since the ninth, performance to set up the "yunnan folk song and dance music cloud to 
award" and so on a series of measures. Goal is to make yunnan folk song and dance performance continuous improvement and perfection, actively promoting national folk song and dance music is getting better, continue to get good grades, more better to launch more better to the national people's fine arts, advance the pace of positive health upward.

\section{The significance of Yunnan folk song and dance music performance}

More than and 10 years, truly Yunnan dance music performances, art fruits, mining art talents, strengthen training successors, enhance national cultural identity, pride; promoting national unity, friendly and harmonious atmosphere, mutual exchanges, learn from each other, improve together, fully demonstrated the harmonious development the people of all nationalities live together in peace together, the spirit of the times, to further strengthen national cohesion and national unity agglomeration plays a positive role in the positive energy, for the construction of national culture in Yunnan province and the national unity and progress, and continuously meet the growing cultural needs of the masses of all ethnic groups, people of all ethnic groups continue to broaden the appreciation, participation and sharing of culture and art platform. Grassroots common experience of the latest achievements in the development of national culture and prosperity, promote the Yunnan intangible Cultural heritage protection, heritage, innovation and development of an important cultural events. Practice has proved that performance of ten years, Yunnan folk music festival held in the nation is one of the most important measures to protect the Yunnan minority folk art treasures, to save many endangered species of art exhibition, the achievement is getting better and better, more and more complete, constantly explore the new scheme summary performance, make the dance music always maintain the correct direction, and constantly improve, to develop healthy and stable. Also marks the singing and dancing performances have been from the past to the rescue collection inheritance and development direction and create art for the target.

\section{The innovation and development of Yunnan folk music and dance performances}

Our province ethnic folk cultural resources has experienced changes in thousands of hundred years of history, folk art culture in different periods and ethnic interaction, from fusion, folk art of ethnic culture and art factor maintains its national characteristics and absorb the essence of other ethnic art, evolved the unique artistic characteristics of the national culture. Performances of Yunnan folk music of various nationalities in Yunnan are interconnected to observe and learn from each other, enrich and draw fresh blood full of vigor and vitality of an opportunity. The national folk dance music performances continued vitality development need to do:

Inheriting folk activities. Yunnan minority unique folk customs, colorful folk culture. Such as: the torch festival of yi, miao festival festival, JingBo wood brain ZongGe, dai and deang water-sprinkling festival and so on. All nationalities in the original form of the traditional song, dance, music performances are contained in the ethnic folk activities in practice. Changing along with the social ecology, folk folk activities also produces change, in a lot of song and dance music of the folk custom activity with the passing of the old artists also disappearing. So the inheritance of folk culture activities and important, the government should vigorously support across ethnic folk culture and folk custom activity, song and dance music in the form of native to protect the heritage, is the root of the folk song and dance music performance creation.

Stage performance set in the corresponding life and folk scene. Folk artists or inheritance people took to the magnificent stage native performance, the audience did not understand the national cultural space of life, it is difficult to understand the cultural connotation of performance. Set up on the stage show, therefore, life in the old form of a song and dance music and cultural landscape, stage props, costumes, such as authenticity, performance on the stage in the design scenario simulation in place as far as possible, at the same time also can science and technology of multimedia with music, singing and dancing on the big screen on the corresponding life scenes or folk activities. This helps to let the audience to deepen understanding the national cultural connotation of expression. 
By using modern music media, impels the national folk song and dance performance influence. By using modern technology development of mass media, newspapers, periodicals, radio, television, movies, audio and video products, a variety of media, such as the Internet [7]. Use of national tourism resources in our province has a distinctive rich variety of advantages, the development of folk culture tourism resources, at the same time to create a website for Internet users to click to watch the demonstration of every program; Create combined with tourism website, attract domestic and foreign tourists travel to yunnan, tourist attractions, for window, combined with the native dance music performance program, or adaptation of the fine arts in the tourism area of commercial performances, can obtain certain material wealth at the same time, more important is to show the results of the promotion and spread and has been widely accepted. Such propaganda radiation most widely, social influence, let more visitors feel at home and abroad of yunnan colorful traditional culture and local national folk art charm of traditional national culture. Folk song and dance music performance results to survive, continue, innovation and development, will have greater artistic vitality.

Let Yunnan folk dance music performances into the campus. Our province folk singing and dancing performances into the primary school and middle school and college campus communication is very necessary. The folk heritage of outstanding artists regularly come in the classroom to teach students. This conscious communication students can touch the mind and soul, cultivating students' love of folk songs, establish students' sense of national pride, sense of responsibility, from the attention of the folk music culture, folk dance music, let me carry forward, at the same time to protect and inherit the traditional music culture in our province to.

Development and innovation, the introduction of fine arts is fundamental. Development and innovation is the key to keeping the contemporary spirit and vitality of folk song and dance. To protect the original form and reference to protect the diversity of innovation and development combined with the premise of innovation and development of traditional folk music and dance music, to be selective and innovation of the folk art tradition of art creation, the original elements for dismantling and refining elements, reconstruction processing into a new art, one of the finest inheritance art and culture factors, so as to keep its vigor and vitality. The inheritance and development of folk songs is folk traditional culture to adapt to the change of contemporary social development needs, meet the aesthetic needs of modern people, so as to promote the national folk dance music for its development and progress.

To find the combination of folk art for the original form of the diversified ecological environment, to inject new blood to the original folk dance music note dancing, to adapt to the public aesthetic taste. Therefore, the creation of prominent national characteristics and contemporary aesthetic consciousness; style to highlight the regional characteristics, close to people's life, with the life of modern people's aesthetic taste, from the creation to realize performance consciousness, from the traditional folk customs and the combination of modern culture, the creation of new art works to preserve traditional culture and root soul. Create a boutique exhibition art, led by the government, director, experts, creators, artists, strict organization planning, the selected theme, making creative plan and specific implementation plan, and the establishment of performing arts groups, scale, level and target at the same time, strengthen the construction of team performance. To do a good job of organization planning, ensure that the national dance music art high quality level; to focus on innovation and creativity, promote national dance boutique times; to strengthen market awareness, promote the national dance music creation of fine long-term development; to increase publicity efforts for national dance boutique creation to create a good atmosphere; with a high sense of responsibility and sense of mission as the creative power, as soon as possible the introduction of a number of high level and high quality folk dance art. The Yunnan folk song and dance and music performances, "dance", to create a similar cloud "day" and other works of art Yunling Lai, Yunnan folk songs to show their style in the modern stage. Based on the traditional and modern folk oriented, rooted in the soil, which is an important experience of Yunnan folk dance music performances in the vigorous development of the contemporary. 


\section{References}

[1] [2] [3] [4] evil spirit lee. Under the lights of the field - minority theatrical festival research [M]. Beijing: the communication university of China publishing house, 2009:3,1,232-234262 263.

[5] Qujing cultural sports. Qujing cultural [M]. Publishing group in yunnan province, yunnan people's publishing house, 2014-9.

[6] He Guangshu. Where does that leave folk song and dance music [J]. Journal of national art research, 2014, (2) : $142 \sim 142$ ).

[7] Wong kin yuen, hence gold. Spread of music and music communication - the third music academic conference on [M]. Nanjing university press, $2008321 \sim 322$. 